\title{
FOREST TAXATION IN BRITISH COLUMBIA ${ }^{1}$ \\ BY IAN MAHOOD
}

Victoria, British Columbia

In British Columbia, the entire forest economy has been developed on liquidation of virgin timber. The Government forest revenue structure has been designed to suit. It is based, primarily, on a system of leases of cutting rights, annual renewal fees and royalty, and to a minor extent on annual property tax on privately-owned timberland.

The licensing and royalty system, in which the timber cutting rights were granted free under agreement to pay an annual renewal fee plus a royalty at the time of logging, developed for two chief reasons.

(1) It was a carry-over from Colonial tradition that all unoccupied territory be retained in the name of the King.

(2) Prior to 1910, the sale of timberland was rejected as a means of raising revenue for the Provincial Treasury for the reason that such sales would not produce any sustained revenue.

In the first decade of the century, land on Southern Vancouver Island, which contained some of the best virgin fir stands in the world, sold for $\$ 5.00$ per acre. To get a million dollars revenue per year from land sales, the Government would have had to sell 200,000 acres of such land. There was not enough accessible and then valuable land available or sufficient customers willing to purchase to provide any substantial revenue from sales. Moreover, if the timberland had been sold, the annual tax would have amounted to less than 10 cents per acre. Therefore, in the early days of the Province the sale of land was not a practical solution to revenue requirements. In 1902 the need for revenue was critical. The timber licensing system was organized to encourage individuals to take up timberland in quantity.

In 1903 legislation was passed which allowed free staking of 640-acre tracts of timber. The grant was for a five-year period, renewable at discretion on payment of an annual renewal fee of $\$ 140$ per year on the coast and $\$ 115$ in the interior. The filing of a claim required 5 years' fees be paid in advance.

The result was that between 1903 and 1907 speculation in this free timber was rampant, and 15,000 licenses were issued and some $\$ 10,000,000$ poured into the Provincial Treasury.

By 1907 practically all the then accessible timber was staked and the objective accomplished, 26 per cent of the Provincial budget was sustained by revenue from renewal fees and royalty as timber was cut.

From the operators' standpoint, timber-cutting rights were available at a low capital outlay with renewal fees that were not too onerous. After all, an agreement to defer payment for an existing asset until an income is realized is a fairly good proposition.

Therefore, the royalty and licensing systems were generally beneficial to Government and operators and much can be claimed for it in this regard. It must be realized that the system developed, as it operates today, primatily

\footnotetext{
1. Paper presented at a meeting of the Vancouver Section, C.S.F.E., March 29, 1950.
} 
because it suited the economics of forest liquidation and it was the most effective expediency possible to allow British Columbians to live for the moment off their forest resources. It should never be concluded that this system was devised because it was suited to forest management or desirable as a means of retaining for the public, a fair share of the natural timber resources endowed on this Province.

In British Columbia, through the medium of land grants to railways and the sale of timberland prior to establishing a clear policy on timber licenses, nearly 20 per cent of the most valuable coast timber was alienated in fee simple. Such land is subject to annual property taxes based on the value of timber held. This system of taxation is suited to liquidation cutting, but like royalty has limitations when projected into a tree farming operation. For example, take a typical property in the E. \& N. Belt. As the property tax operates, if an owner decided to undertake forest management, his annual tax payment per MBM would increase three to four times over a liquidation cut. The reason for the sharp increase is twofold. First, to sustain the operation, it is necessary to keep timber in reserve until the second crop is available for harvest. Since the property tax is on the reserve of mature timber, the longer the mature timber is conserved, the higher the tax. Conversely, the more rapid the cut, the lower the tax. Secondly, the assessed value of the land includes the value of the crop. As this crop grows it increases in value and is taxed annually over and over again. Therefore, under an 80-year cutting cycle, the first part of the crop is taxed 80 times. The result is a tax equal to $3 / 4$, of the value of the crop.

The forest economy is changing. Forestry is in a transition period and is developing into growing trees as a crop. The place of the license and royalty system and the annual property tax in the new economy requires some detailed examination. There are two main reasons. Firstly, direct charges on a timber crop are simply a first mortgage claimed by the Government on the production of a raw material. The better the quality or quantity of wood produced, the higher the payment to the Government. In other words, the more successful and efficient an operator is, the more he pays. Such a tax form is characteristically most regressive and can be a deterrent to economic and sound forest production.

Secondly, in addition to the transition of forestry to second crop production, the entire economics of the tax structure is changing with an emphasis which suggests that direct charges on a tree crop may be undesirable.

The Changing Tax Structure

Adam Smith advocated that taxes should be levied with as little hindrance to production as possible. The popular version of this is "Don't kill the goose that lays the golden egg." There has been no essential change in this proposition but it has been elaborated upon and now taxation has been elevated from a simple revenue medium to an instrument of economic policy.

During the war, the Dominion levied high income taxes and numerous indirect taxes with the purpose of draining off purchasing power to retard inflation. Since the war, economists have advocated gradually decreasing the tax level with the dual purpose of increasing purchasing power and maintain- 
ing a high level of production. This is the cyclical budget principle which is a part of modern government. The type of tax needed for this operation are income taxes and taxes paid out of purchasing power. High direct charges on productive sources are not suitable.

The result is that from a revenue standpoint as well as a social political policy there is great importance given to maintenance of adequate employment. This is likely to ensure that each component of the tax revenue structure, whether it be in the Provincial or Dominion sphere, will be considered from the standpoint of its influence on production and employment.

Sustained production and the creation of stable employment is one of the main arguments for forest land management. If follows that the forest tax structure should not be such that it operates in the opposite direction.

It must of course be recognized that taxes are a part of the democratic way of living we enjoy. Giving attention to the impact of taxation on production and employment does not mean we can neglect other objectives of taxation, such as provision of adequate revenue, ability to pay, fairness and public acceptance. A sensible tax programme should be based on a balance of all these considerations. A look at the British Columbia revenue structure, and appreciation that nearly 50 per cent of our economy is dependant upon forestry, suggest that greatest emphasis should be attached to stimulating forest production.

the Revenue Structure in British Columbia

The 1950-51 estimates of revenue are as follows: Dept. of Attorney General

Fees, licenses, etc. $\$ 2,558,000$

Motor vehicle fees $6,375,000$

Gov. Liquor profits $16,800,000$

Dept. of Finance $\$ 25,733,000$

Dominion Gov. Grants $\$ 28,603,439$

Gasoline \& Fuel Oil Tax $12,050,000$

Amusement Tax, Horse Racing $2,900,000$

Property taxes

$1,850,000$

Mining Tax (output) ............................. 1,700,000

Sales tax ........................................... 24,000,000

Misc. fees, Poll tax, etc. 845,000

Dept of Lands and Forests

Sales of Land $\$ 71,948,439$

Sales of timber \& royalty 315,000

Lease and License fees $5,750,000$

Misc. Revenue 440,000 780,000

Misc. Revenue all other Departments

Total estimated revenue

$\$ 105,831,189$

It will be noted that the Department of Lands and Forests which handles practically all income from resources obtains 6.8 per cent of the revenue. This 
Department requires a large expenditure in administration. In 1950-51 the expenditures are estimated at $\$ 6,427,520$ or 89 per cent of revenue. This is in contrast to the two revenue Departments of Attorney General and Finance which expend 20 per cent and 19.6 per cent of revenue they collect. A glance at the revenue of these two departments shows that practically all revenue is from purchasing power and income tax.

By adding direct taxes on property and resources it will be seen that direct charges are less than 10 per cent of all revenue. Therefore, it is apparent that 9 out of every 10 dollars revenue comes from production and employment. The apparent way to stabilize Provincial revenue, and expand it, is to increase production and provide employment which will attract a population and thereby increase the purchasing power. The plain truth is that what is needed in British Columbia is more people driving cars, buying capital goods, drinking alcoholic beverages and going to places of amusement.

The foregoing is a radical change over the revenue pattern in the past.

In the decade $1905-14$ forests produced $26 \%$ of revenue.

In the decade 1915.24 forests produced $26 \%$ of revenue.

In the decade $1925-34$ forests produced $15 \%$ of revenue.

The present estimates show forest producting 4.5 per cent of the revenue.

The proportion of forest revenue returned for administration, protection and maintenance of forest resources has been

$1915-1924$ about $16 \%$

$1925-1934$ about $22 \%$

The present expenditure is 77 per cent and the actual requirement for sound forest management is much higher. It is but a short time until it will be necessary to expend on public forestry more than is received. The additional revenue must come from other tax sources, which means greater emphasis on producing to maintain these sources. This suggests that foresters ought to consider the effect of royalties, taxes and other direct charges on the capacity and incentive of forest industry to produce and provide employment.

\section{Dominion Provincial Tax Organization}

Like the British Columbia revenue set up, the Dominion tax structure depends almost entirely on industrial activity and purchasing power. It is important that the Provincial and Dominion Tax Structures be co-ordinated. The report of the Royal Commission on Dominion Provincial Relations, Book 11, Page 113, stresses this point as follows:

"The present complexity in business taxation is beyond belief. The most important item is the corporation income tax levied by the Dominion and most Provincial Governments. There are in addition, taxes levied by one or more governments, on various bases. .... These taxes have grown up in a completely unplanned and unco-ordinated way, and violate every canon of sound taxation.

As a result . . . certain forms of business can be and are singled out for discriminatory taxation; tax compliance costs are uselessly and unreasonably increased. And again, it should be added that the same amount of revenue could be secured without imposing any of these discriminatory and inequitable burdens." 
There are many advantages to co-ordinating the tax structure. It is fairly certain that in the long run tax adjustments, to control purchasing power and industrial expansion which are likely to be a permanent part of the Dominion programme, can be retarded by a high level of direct taxes levied by the province, particularly land and timber crop taxes. Such taxes are unmistakably most regressive and can do much to retard forest crop production.

The Importance of Public Opinion on forest Taxation

Foresters should understand the broad tax structure we operate under. Proposals completely divorced from it, can hardly be expected to provide the forest tax system with the element of stability so necessary to tree crop production. Special favourable forestry taxes are not necessarily a solution since it must be remembered that any special tax tends to shift the burden. The shifting of taxes from forestry to another business is a clear gain for the former and a clear loss for the latter group. The result may only be a conflict of interest. Clearly no forest tax system will provide any lasting good unless it is in harmony with all interests and is acceptable to the public on that score.

There are a number of sound and equitable forest tax methods based on ability to pay, which could suit the revenue needs and economic policies of both the Federal and Provincial Governments. However, before any one of them can be adopted, the public must be informed on the need for a change.

The public thinks in terms of "vast natural resources which are the public heritage". A political philosophy has developed on public control of logging, forestry and forest revenue. These ideas are not confined to socialists. Even the most rabid "laissez faire" economists, instinctively and without sound economic justification resent successful development of natural resources and consider high forest taxes necessary in the public interest.

The Report of the Royal Commission on Forestry states that 24 out of 677 logging operators produce 60 per cent of the coast timber. Many people are disturbed by this fact and interpret it as bad economics and a monopoly condition. An illogical but popular belief is that higher direct payments to Government will restrain such developments. It is of course a fact that the 677 competing operators do not constitute a monopoly. It is also patent that many of the 653 operators producing 40 per cent are likely to be forced out of business by an overall increase in taxes or Government charges for timber. Moreover, the high cost departments of large industries might be curtailed. The result would be reduced production, reduced employment and reduced Government revenue since 9 out of every 10 dollars comes from production and employment.

This pressure to increase royalty and taxes on forest industries, that is, "to get more out of natural resources" is strong. It will be difficult to overcome this until the public begins to think in terms of second crop forestry rather than virgin resources.

Public opinion cannot be ignored if forestry is to be developed on a secure basis. Foresters will need to accept a responsibility to educate the public. It is logical to approach forestry and forest taxation from the angle of maximizing production because to the public this means employment and industrial activity. It is in this field that the harmonies of interest are strongest between Government, industry and the public. It is to be hoped that in advocating 
reasonable and economic taxation the great importance to the public interest can be emphasized and that this proposal will command enough support from enough sensible people to ensure acceptance.

\section{EQUALITY OF TAXATION}

Forestry is a crop production business which needs no tax subsidy and can well afford to pay a fair and equitable tax at the levels charged other crop producing enterprises.

The problem is that forestry is not being treated on this basis.

Regulations of the income tax laws are inequitable as they apply to the forest industries and forest land management.

In British Columbia privately-owned forest land is charged forest protection tax at 6 cents per acre, school tax and land tax several times farm land rates. Moreover, the assessment procedure visualizes assessing the crop over and over again annually.

At the other extreme, publicly-owned forest land is leased for forestry purposes with an exemption from land and school taxes and forest protection tax on a per-acre basis. There is substituted an agreement to purchase from the Crown virgin timber as cut at the prevailing stumpage price. When the second crop reaches maturity and is cut, the land occupier can pay 16 per cent of the stumpage value net of logging, protection and forestry costs. Under this arrangement, the Government will receive no revenue, except for the nominal statutory payments unless a positive stumpage value can be determined. The result is that the Government is virtually guaranteeing the land-user a profit before any tax share is claimed.

This arrangement approaches taxation from the angle of maximizing production and has many advantages but it may be vulnerable on the score of public acceptance.

In comparison to the annual property tax payments required of all other occupiers of Crown land and private land owners, an important tax concession is granted one group of land users. The concession is so favourable that it may be misunderstood by other taxpayers.

The large acreages of Crown land allocated to big industry under a management license and the exemption from like tax treatment are two features which the public has instinctively disliked. In general, the forest management license agreements aim at sustained forest production at the outset. There results an annual income from operations. It may be difficult for the public to understand why an annual land and school tax cannot be paid. This is particularly true since until the mature timber is removed, payments to the Government are the non-competitive purchase price of Crown timber in which no tax is involved.

The fact that taxes on private forest land are maintained at high levels, does not add any weight to the necessity for the tax exemption granted lease holders. The difference can hardly be justified with the argument that all forest land should be turned over to Crown ownership for allocation under lease since the majority of the public are likely to be more impressed by revenue than differences of land ownership. 
There is no firm agreement with respect of taxes under the management license agreement. The contract does not specifically mention a tax exemption or a schedule of payments. These are defined by Statutes which are subject to change at the will of the Legislature.

So long as land taxes form a major tax method on small holders, it is to be expected public opinion will require that;

(a) Industrial land pay a comparable tax.

(b) The reputedly wealthy forest industries can have less expectation of occupying, with tax concession, large acreages of land, whether it be licensed from the Crown or held in fee simple.

The property taxes in British Columbia are at present based on differential tax rates, in which land suitable for growing trees as a crop is taxed at 6 times ordinary farmland and industries are taxed at 2 to 3 times small holders.

These differential tax rates are an inherent obstacle to equitable forest taxation.

In the U.S.A. under article 1, Section 2, Clause 3 of the Constitution there is a legal barrier to unequal rates, and forest landowners can develop tree farms without having to contend with a statutory unequal tax rate. The British North America Act does not afford B.C. landowners the same safeguard.

In B.C. growing of trees as a crop cannot be rated as sufficiently profitable to support a higher tax rate than normal for other businesses. On the other hand, a sustained forest business ought to be able to pay an equitable annual property tax since an annual income is obtained.

In their zeal to establish sound forestry, foresters often seem to have assumed that growing trees as a crop is inherently unprofitable and will require subsidy either from Government or the wood-using industry. In other words, all Government forest revenue and the profits of the sawmill and pulpmill must be returned to the land.

This approach seems to be wrong. In other forest areas of the world with forestry conditions less favourable than B.C., tree farms operate without subsidy from the public and are independent of the manufacturing plant. It is felt that it is sound that separation of tree crop production and manufacturing operation be an objective of forest development. In this way tree farming can develop as a profitable crop-producing business.

This means that our forest land tax structures should not be aimed at the profits of the few integrated wood-using industries. The income taxes can take care of these earnings. Our property tax needs to be based on the value of tree farms in their relation to their ability to produce income. This point is essential, if we are going to develop tree farms under a large number of owners, because under our constitution forestry requires the support of a large number of voters if a sound and equitable system of taxation can be developed and maintained.

\section{The Type of Property Tax}

There are many schools of thought on types of forest land taxation. Three methods are most often discussed.

(1) A Yield tax; which is a fixed payment or a percentage of stumpage value at the time of harvest. 
(2) Deferred tax. The annual payments are recorded and deferred until harvest.

(3) Annual Property tax, based on value of the land.

The Yield tax is very consistently advocated in spite of the fact that enforcement is ultra vires of the Provincial Legislature except by way of contractual agreement. The history of tax agreements has been sufficiently unsatisfactory that they should be avoided.

In the U.S.A., where the overall tax structure is similar to B.C., there has not been general use of the yield tax.

The Fairchild study did not advocate a yield tax. The reasons were that maximum forest production was discouraged by removal of incentive, the tax burden was seldom equitable with other property and the revenue received was unpredictable and unstable.

In B.C. we depend upon income taxes and maximum employment for revenue. There seems to be little point in advocating a yield tax which is in reality a form of income tax. An increase or adjustment of income tax could be more efficient and would avoid duplication of collection.

The Government requires a stable tax to provide basic school and general services. Land taxes have always been used for these purposes and are likely to be retained.

The Fairchild study recommended a property tax method, modified by scientific assessment and an economic tax rate. In special cases some deferment of taxes may be necessary so that it is felt that the Deferred tax and property tax plan have the best chance of success in B.C., bearing in mind the importance of public opinion and the need for equitable taxation.

\section{AsSESSMENT PRocedure}

One of the most difficult fields of agreement, even among foresters, is what constitutes forest land value. The main point of issue is whether land value should include the value of the trees. If we accept forestry as crop production then surely the trees are the crop. Land value is then measured by the ability to produce a crop, adjusted for the factors of accessibility, topography and fire risk. Basically, this would be valuation on the basis of site quality.

It is true that an acre containing 50-year-old timber will sell for considexably more than an acre of 10 -year-old seedlings. It is felt that the difference should be considered crop value rather than property value.

In ordinary farming the assessment procedure does not value the crop on the land. Land value is influenced by the type of crop and the quantity that can be produced. The crop is considered as belonging to the man who grows it. The income Tax, sales tax and purchasing power created by wages paid to farm labour provides the source of Government revenue. This type of tax economy explains in no small measure why much low-grade agricultural land can be profitably tilled. A similar assessment procedure applied the forest land value with an equitable tax rate seems logical.

Sound valuation of forest land will require forestry data on site, rotation and estimated income. It remains to correlate this information and 
discount income to present values. Many people are concerned about future stumpage values. This is relatively unimportant since all estimates are based on current stumpage prices and land valuation can be changed annually or as often as conditions warrant.

It is fairly certain that assessment of land and tree crop annually is impractical. It simply means that value spirals as maturity is reached. The crop is assessed over and over again annually. The result is a tax spiral which, without interest, will absorb most of the crop value.

The risk of loss rather than low-profit margin is the greatest obstacle to tree crop production. Royalties, taxes on crop when harvested and an annual tax on increment are in reality an unspecified first mortgage held by the Government on the crop value. There would seem to be little encouragement for people to enter a tree farming business on a share cropping basis. Such forms of taxes do not appear to suit the need for maximum employment and production. It would seem that the public interest can be adequately served by an annual land tax which participates in general and school cost supplemented by the income taxes normal for all businesses.

In special cases where sustained production has not been reached and no income is received, it would seem to be proper to defer annual payments, with interest, until income is received. This is not a change in tax form but in merely a payment option.

Many people are worried that ownership of land containing timber which is untaxed will lead to speculation in land and timber. Speculation is risktaking which is highly desirable if we are to have a dynamic economy. People who take risk perform a social duty. So long as forest land is kept productive and there is protection against destructive exploitation of resources there is nothing to worry about. Therefore, by advocating a tax system that might stimulate speculation in forest land ownership for the accruing value of second growth, one objective would be attained and forest crop production would be sold to the public. It would remain for the Government to enforce regulations in the public interest, which would prevent destructive exploitation of such crops.

\section{CONCLuSroN}

In this paper, an attempt has been made to outline the broad tax structure and show that it is developing to maximize production as well as to provide reasonable revenue. It is felt that forest taxation should be designed to fit into this pattern. The most adaptable tax method seems to be an annual property tax on land value, with greater dependence on income tax, after the tree crop is realized.

This proposal is in line with the trend of taxation. The other advantages are avoidance of direct charges on the crop and therefore an incentive to sound forestry, production, equality with other crop-producing businesses and a reasonable pattern which should have public acceptance.

There is no intention to convey the impression that taxes are the only forestry problem. However, if forestry could be treated as a crop-producing enterprise, there are likely to be fewer forest problems. 